\title{
The Regulation of Illegal Fundraising in China
}

\author{
Xinmin Liu (East China Normal University) \\ E-mail:xmliu@law.ecnu.edu.cn
}

Flora Huang (University of Essex)

E-mail: flora.huang@essex.ac.uk

Horace Yeung (University of Leicester) [Corresponding Author]

E-mail: horace.yeung@le.ac.uk

\begin{abstract}
The rise of financial technology means that it is easier than ever to raise funds from a large group of people, notably via $\mathrm{P} 2 \mathrm{P}$ lending or crowdfunding platforms. This article seeks to discuss the law on illegal fundraising, which has existed for some time before the boom of the Internet, as a legal response to the increasing number of fundraising from the public. Regulation is necessary to ensure market order and investor protection. Virtually in all markets, there are restrictions on how entities can make a public offer of shares, bonds, and/or other investment schemes. There are several laws, most notably criminal law, in China that are relevant to illegal fundraising. An individual/company can potentially breach one or more of these rules as long as they attempt to raise funds from a non-conventional (i.e. not stock markets or banks) route. The worst outcome of this used to be death penalty. There has been a degree of ambiguities in the application of these laws. The article will attempt to clarify these ambiguities. The regulation of illegal fundraising can have a far reaching consequence on the financial markets in China, considering that non-state entities, particularly SMEs, have limited access to conventional finance. The article will consider whether China is on the right track in terms of regulation to allow alternative fundraising channels to thrive. This article is the first ever to present a holistic account of the regulation of illegal fundraising in China.
\end{abstract}

* The authors would like to thank all the participants, in particular Iris Chiu, Ming Du, Huachun Guo, Junhai Liu, Fang Ma, Agasha Mugasha, Boya Wang at the workshop 'Ethics and Challenges in Chinese Financial Markets', University of Essex, 25 March 2017, for their helpful comments and feedback. The suggestions from two anonymous reviewers are also gratefully acknowledged. The usual disclaimer applies. 


\section{Introduction}

The rise of technology means that funds can be raised from a large group of people easier than ever. The fall of Ezubao ${ }^{1}$, a peer-to-peer online lending platform, has angered and shocked the whole country of China, including the head of state, Xi Jinping. Whilst the rise of Financial Technology, in short FinTech, and the regulation of it, has caught the attention of scholars $^{2}$, this article does not wish to go down that path. Instead, this article seeks to focus on the very law regulating illegal fundraising which has existed for some time, before the boom of the Internet, and been applied in cases such as Ezubao. Illegal fundraising is not exactly a recent phenomenon. In Securities and Exchange Commission v. W. J. Howey Company $^{3}$, a case decided in 1946 in the US, the core legal issue was whether an offering of units of a citrus grove development, coupled with a contract for cultivating, marketing, and remitting the net proceeds to the investor, would constitute an offering of an investment contract' within the meaning of that term as used in the Securities Act of 1933 of the US and therefore require registration under the law. The importance of the case was that, it set out a landmark test, known as the Howey test, to determine whether an instrument qualifies as an 'investment contract' for the purposes of the Securities Act. At the end, Howey was found liable for violating the law.

Likewise, the agricultural sector used to be the focus of China in this area of law. The People's Bank of China (PBOC) issued the Emergency Notice on the Use of Manor Development for Illegal Fundraising ${ }^{4}$ in 1998 to explicitly ban cases like Howey. Shortly before that, in 1997, China revised its Criminal Law for the first time since it had been introduced in 1980, to include sections for the crimes collectively known as 'crimes of undermining the order of financial management' and 'crimes of financial fraud'. 5 This was part of an integrated strategy to curb the problem. The strategic role of the financial markets in supporting sustainable economic growth was formally recognised in 2004, when the Opinions of the State Council on Promoting the Reform, Opening and Steady Growth of Capital Markets were issued. ${ }^{6}$ Promoting capital markets and increasing public awareness of their importance are regarded as national strategies. Further, the Opinions advocate the need to strengthen the legal and regulatory framework and step up enforcement efforts to maintain market order and protect investors' interests. In 2010, the Interpretation of the Supreme People's Court of Several Issues on the Specific Application of Law in the Handling of Criminal Cases about Illegal Fundraising was issued. ${ }^{7}$ The Interpretation on the one hand upholds the criminal nature of illegal fundraising, but on the other hand provides leeway for cases when funds are raised for 'normal manufacturing or business operation and the

\footnotetext{
${ }^{1}$ More to be discussed below on this case.

${ }^{2}$ See for example, Weihuan Zhou et al., 'Regulation of Digital Financial Services in China: Last Mover Advantage' (2015) 8 Tsinghua China Law Review 25; Douglas Arner and Janos Barberis, 'FinTech in China: From the Shadows?' (2015) 3 Journal of Financial Perspectives 78; Long Chen, 'From Fintech to Finlife: the Case of Fintech Development in China' (2016) 9 China Economic Journal 225; and Haifang Yao et al., 'Study on P2P Lending Regulation' (2015) 3 Renmin Chinese Law Review 92.

${ }^{3}$ Securities and Exchange Commission v. W. J. Howey Company 328 U.S. 293 (1946).

${ }^{4}$ Order No. 509 (1998) of the People's Bank of China.

${ }^{5}$ Chapter III Sections $4 \& 5$ of the law.

${ }^{6}$ Order No. 3 (2004) of the State Council.

7 The Interpretation was adopted at the 1,502nd session of the Judicial Committee of the Supreme People's Court on 22 November 2010, and came into force on 4 January 2011.
} 
borrower can return the entire solicited fund within the required time...or if an act is obviously of minor importance'. 8

This article will be divided into four main sections. Part II will discuss the theoretical underpinnings in this area of law. Part III will discuss the trajectory of the laws regulating illegal fundraising. Whilst the main legislation is the Criminal Law of China, the part will concern its connections with other laws ${ }^{9}$ which can function together with the Criminal Law as a whole regulatory package. Any notable court cases related to illegal fundraising will be discussed. Part IV will proceed to discuss the causes of the prevalence of the problem. These are stemmed from the demand and supply side factors. On the one hand, entrepreneurs have been baffled by the limited fundraising channels in China. On the other hand, an unusually high saving rate in China means that there is a need to properly channel these savings to productive use to foster economic growth. Part $\mathrm{V}$ will discuss whether China is heading towards the right way to regulate illegal fundraising before a conclusion is made. This article is the first ever to present a holistic account of the regulation of illegal fundraising in China.

\section{Theoretical Underpinnings of Regulation in this Area}

The concerns underlying the context of this article are twofold: first the need to regulate an 'investment contract' as in Howey; second the need to regulate entities functioning as a 'bank'. In the view of MacNeil, the bottom line is, contract and property law should be capable of providing a basic degree of protection to investors. ${ }^{10}$ Contract is the primary mechanism through which rights and obligations associated with investing are created. For example, company shares can be regarded as a 'statutory contract' that links a shareholder with a company and the other shareholders. ${ }^{11}$ The contract exists predominantly in the form of the articles of association of a company which define various rights of shareholders, such as voting rights and the right to dividend, and the distribution of power within a company. ${ }^{12}$ On the other hand, one key concept in property law is ownership. Ownership is a set of legal rights held by an owner in respect of a property, be it tangible like a piece of land or intangible like most types of financial investments. In the context of China, the Contract Law was enacted in 1999 and sought to protect 'the legitimate rights and interests of the parties to contracts, maintaining the socio-economic order and promoting the socialist

\footnotetext{
${ }^{8}$ Art 3 of the Interpretation.

${ }^{9}$ These laws include, but are not limited to, the laws issued by the Standing Committee of the National People's Congress such as the Decision of the Standing Committee of the National People's Congress on Punishment of Crimes of Disrupting Financial Order [Order No. 52 (1995) of the President of the People's Republic of China; administrative regulations issued by the State Council such as the Measures for Banning Illegal Financial Institutions and Illegal Financial Business Activities [Order No. 247 (1998) of the State Council; revised in 2011 by Order No. 588 of the State Council]; government regulations issued by government departments such as General Provisions on Lending [Order No. 2 (1996) of the People's Bank of China]; judicial interpretation issued by the Supreme People 's Court such as the Interpretation of the Supreme People's Court of Several Issues on the Specific Application of Law in the Handling of Criminal Cases about Illegal Fundraising [Interpretation No.18 (2010) of the Supreme People's Court]; and so on.

${ }^{10}$ Iain MacNeil, An Introduction to the Law on Financial Investment (Hart, 2012) 8-9.

${ }^{11}$ Such a view is recognised by for example, section 33 of the UK Companies Act 2006.

${ }^{12}$ Under Art 11 of the Chinese Company Law, to establish a company, the articles of association shall be formulated according to the law. A company's articles of association shall be binding upon the company, shareholders, directors, supervisors and senior officers. The Chinese Company Law was first adopted at the 5th Session of the Standing Committee of the 8th National People's Congress on 29 December 1993 and last revised on 28 December 2013 in at the 6th Session of the Standing Committee of the 12th National People's Congress.
} 
modernisation'. ${ }^{13}$ According to Matheson, there is a degree of convergence between the Chinese Contract Law and that of Western economic and legal systems. ${ }^{14}$ Western economists and historians have long emphasised the importance of institutions. ${ }^{15}$ The institutions hypothesis alleges that societies with a social organisation that provides encouragement for investment will prosper. This new movement of institutional economics has generally identified itself as an attempt to extend the range of neoclassical theory by explaining the institutional factors traditionally taken as givens, such as property rights and governance structures. ${ }^{16}$ Whilst contractual rights can be regarded as a form of property, the first Property Law in China was not introduced until 2007. ${ }^{17}$ On the one hand, adoption of the Property Law is viewed as a 'substantial step toward protection of private property rights' 18 On the other hand, how private property rights can be enforced in a country where the public or state ownership is still playing a leading role is questionable. ${ }^{19}$

La Porta and colleagues argue that optimal regulatory arrangements can be distilled down to three broad hypotheses. ${ }^{20}$ The very liberal approach implies that the optimal government policy is to leave financial markets unregulated because the market and some general legal mechanisms are sufficient for the markets to prosper. A less liberal approach suggests law is necessary owing to the consideration of enforcement costs and opportunistic behaviour of market players. One option is the standardisation of the private contracting framework to improve market discipline and private litigation through specialised law, most notably securities law. Ultimately, governmental intervention may be desirable when all existing markets, legal mechanisms and private enforcement incentives are deemed insufficient. Therefore, a public enforcer is needed to support trade. Public enforcement may work because the enforcer is independent and focused. In the context of this article, the highest level of regulation is witnessed around the world. For example in China, there are the China Banking Regulatory Commission (CBRC) and the China Securities Regulatory Commission (CSRC) overseeing the banking sector and the securities markets respectively. The regulatory objectives of the two are not necessarily the same. According to Allen and Herring, banking regulation is primarily designed to prevent systemic risk while securities regulation is

\footnotetext{
${ }^{13}$ Art 1 of the Chinese Contract Law. The law was adopted at the Second Session of the Ninth National People's Congress on 15 March 1999.

${ }^{14}$ John Matheson, 'Convergence, Culture and Contract Law in China' (2006) 15 Minnesota Journal of International Law 329, 381.

${ }^{15}$ Daron Acemoglu et al., 'Reversal of Fortune: Geography and Institutions in the Making of the Modern World Income Distribution' (2002) 117 Quarterly Journal of Economics 1231, 1262.

${ }^{16}$ Malcolm Rutherford, 'Institutional Economics: Then and Now' (2001) 15 Journal of Economic Perspectives $173,187$.

${ }^{17}$ MacNeil indicates that different legal systems have varied in their recognition of contractual rights as a form of (transferable) property. See MacNeil (n 10) 11. The Chinese Property Law was adopted at the Fifth Session of the Tenth National People's Congress on 16 March 2007.

${ }^{18}$ Mo Zhang, 'From Public to Private: The Newly Enacted Chinese Property Law and the Protection of Property Rights in China' (2008) 5 Berkeley Business Law Journal 317.

${ }^{19}$ Ibid. On a more positive note, Berkowitz and colleagues are of the opinion that the Chinese Property Law by codifying fundamental protections of creditor rights and restraints on the grabbing hand of governments can improve de facto property rights. In their study, they showed that these improvements in property rights can promote firm value and thus economic growth. See Daniel Berkowitz et al., 'Do Property Rights Matter? Evidence from a Property Law Enactment' (2015) 116 Journal of Financial Economics 583.

${ }^{20}$ Rafael La Porta et al., 'What Works in Securities Laws?' (2006) 61 Journal of Finance 1, 1-3.
} 
primarily for investor protection and efficiency enhancement. ${ }^{21}$ As said in the beginning of this part and the next part will also proceed to show, illegal fundraising in China concerns both areas of regulation.

Pan rightly indicates that regulation seeks to achieve certain economic and social objectives. ${ }^{22}$ Economic regulation seeks to address market failures such as natural monopolies, externalities, imperfect information, principal-agent problems, excessive competition, anticompetitive behaviour and disruptive business cycles. Social regulation, on the other hand, attempts to achieve certain social objectives that private persons on their own will not pursue, including distributional justice and access to judicial remedies. MacNeil particularly highlights unrestricted access and information asymmetry as justifications of regulation. ${ }^{23}$ The former clearly has a damaging effect to the market if unscrupulous individuals are permitted to participate. Information asymmetry is also a problem in that investors who lack information may decide not to invest or to limit their investment, narrowing the scope and size of the market.

The banking sector carries three functions: liquidity transformation, maturity transformation, and credit transformation. ${ }^{24}$ The first function allows users to access money for consumption purposes. The second function points to the role of banks to translate shortterm deposits into long term investments. Finally, banks are critical to the financing of individuals and small and medium-sized companies. The system works well in normal circumstances, but at the same time is fragile. One notable example is a bank run. In the event of a large number of depositors withdrawing their investments, the bank may not meet their demands by liquidating assets and cashing in long term investments. Banks' fragility, combined with the important functions they perform, engenders a belief that they need to be regulated. ${ }^{25}$ In this regard, four typical regulatory tools can be employed. The first is to impose capital requirements on banks. The second is to require banks to hold some of their assets in a liquid form. The third is to set up a lender of last resort that stands ready to make loans to banks, and the fourth is insurance against risks of losses on deposits. These tools are witnessed in China. For example, China launched a long-awaited deposit insurance system in 2015. Deposits up to RMB 500,000 are now insured. ${ }^{26}$ Of course, it may have little relevance in the context of this article as it is unlikely that the 'illegal' fundraising schemes will be administered by banks recognised by the PBOC, which is the backer of the deposit insurance system.

In an illegal fundraising scheme, a vast number of the general public are generally affected and suffer financial loss. There is a need to differentiate 'sophisticated' and 'retail' investors. ${ }^{27}$ The latter are generally individuals acting in a personal capacity or small

\footnotetext{
${ }^{21}$ Franklin Allen and Richard Herring, 'Banking Regulation versus Securities Market Regulation' (2001) Centre for Financial Institutions Working Papers 01-29, Wharton School Centre for Financial Institutions, University of Pennsylvania.

${ }^{22}$ Eric Pan, 'Understanding Financial Regulation' [2012] Utah Law Review 1897, 1902-1903.

${ }^{23}$ See MacNeil (n 10) 28-29.

${ }^{24}$ John Armour et al., Principles of Financial Regulation (OUP, 2016) 277.

${ }^{25}$ Ibid. 279.

${ }^{26}$ Gabriel Wildau, 'China Deposit Insurance Paves Way for Deregulation of Interest Rates' Financial Times (31 March 2015). See also Yi Zhou, 'Establishing a Deposit Insurance System in China: A Long-Awaited Move Toward Deepening Financial Reform' (2016) 16 Chicago-Kent Journal of International and Comparative Law 46.

${ }^{27}$ Armour et al. (n 24) 205-207.
} 
businesses in each case dealing with relatively modest sums. Measures are deployed most strongly in favour of investors from this group, where information asymmetry and behavioural biases are so prevalent. Standard legal protections are essential in a scenario where investors are too naïve to protect themselves. There can be various legal strategies. For example, the US's Securities Act 1933 and the Securities Exchange Act 1933 provide two basic sets of rules for investor protection: mandatory disclosure and anti-fraud. ${ }^{28}$ These two elements are often regarded as fundamental to a strong securities market. Around the world, there are two main types of systems for listing shares. One is the registration system while the other is the verification and approval system. ${ }^{29}$ The former is simpler, and is found in the US, the UK, Hong Kong, Australia, Canada, Singapore, Germany and France. As long as the applicant complies with all the prescribed listing requirements, no further procedures are required. In this system, the market is the ultimate decisive factor. By contrast, under the verification and approval system, the relevant authority will examine and verify the documents for listing, and if necessary, disallow the company's listing. Therefore, in practice, the authority has the power to decide whether a company can be listed or not. This system is adopted by China, New Zealand, Sweden and Switzerland. ${ }^{30}$ In this system, the regulator itself is acting as a guardian of quality. This illustrates the attitude of China in financial regulation by maintaining a tighter grip on the markets, when compared to certain leading markets. The question is how intensive we want the financial regulation to be. ${ }^{31}$

Chairman of the Parliamentary Commission on Banking Standards, Andrew Tyrie MP, once observed that:

Despite the financial crisis and the spate of mis-selling scandals, we still have not seen anybody sent to jail. Is that because nobody ought to go to jail, or because there is a fundamental failure in the sanctions regime or the legal system in the UK? ${ }^{32}$

The criminal law is a significant part of the regulation of the financial markets. According to Hudson, the criminalisation of some financial activities is of great importance in the creation of a culture of compliance. ${ }^{33}$ Much of the purpose of the criminal law in the law of finance is either to achieve broader policy goals or to create the impression of the pursuit of broader policy goals. ${ }^{34}$ As in Howey, although the case itself did not involve criminal liability (when only an injunction was sought), the US Supreme Court did point out explicitly that the policy of the Securities Act is to afford 'broad protection to investors' ${ }^{35}$ In the context of China, according to the Opinions of the State Council on Promoting the Reform, Opening and

\footnotetext{
${ }^{28}$ Hideki Kanda, 'Comparative Corporate Governance - Country Report: Japan' in Klaus Hopt et al. (eds) Comparative Corporate Governance - The State of Art and Emerging Research (OUP, 1998) 925.

${ }^{29}$ Alex Lau, 'A Study on Listing Applications in the People's Republic of China' (2007) 28 Company Lawyer 90, 92.

${ }^{30}$ It is worth highlighting that China has been moving towards a registration system. Xie Yu, 'China ushers in new IPO registration system but it's likely to come with "Chinese characteristics"' SCMP (9 December 2015).

${ }^{31}$ For a cross-country comparison, see Howell Jackson, 'Variation in the Intensity of Financial Regulation: Preliminary Evidence and Potential Implications' (2007) 24 Yale Journal on Regulation 253. China has not been examined by Jackson. For the case of China, see Wenming Xu et al., 'An Empirical Analysis of the Public Enforcement of Securities Law in China: Finding the Missing Piece of the Puzzle' (2017) 18 European Business Organization Law Review 367.

${ }^{32}$ Parliamentary Commission on Banking Standards - Minutes of Evidence: HL Paper 27-III/HC 175-III (17 January 2013).

${ }_{33}$ Alistair Hudson, The Law of Finance (Sweet \& Maxwell, 2009) 293-294.

34 Ibid.

${ }^{35}$ Securities and Exchange Commission v. W. J. Howey Company 328 U.S. 293 (1946).
} 
Steady Growth of Capital Markets ${ }^{36}$, China's capital markets have been recognised as 'an important component part of the socialist market economy' by contributing greatly to the reform and development of state-owned enterprises and the financial market, to the optimisation of resources allocation and to the promotion of economic restructuring and growth. Much emphasis has been placed on 'the steady growth of capital markets'. As rightly put by Schultz, the enactment of the criminal law was intended to combat the 'deleterious effects of [certain economic] crimes on China's social and economic development'. ${ }^{37}$ The criminalisation of illegal fundraising clearly has had the mission of preserving the stability of Chinese financial markets.

\section{The Law Regulating Illegal Fundraising}

The starting point of regulation was seen in 1995, when the Law on Commercial Banks ${ }^{38}$ introduced criminal sanctions on those who 'illegally absorb public deposits or absorb public deposits in a disguised way'. ${ }^{39}$ The relevant sanctions are contained in the Criminal Law. ${ }^{40}$ Entities who commit the offence can be sentenced to not more than three years in prison and additionally face a fine of not less than RMB 20,000 but not more than RMB 200,000. For more serious offence when the amount involved is significant, the prison sentence can range from three years to ten years, together with a larger fine of RMB 50,000 to RMB 500,000. Despite designating 'illegal fundraising' as a criminal offence, the law did not attempt to give it a precise definition until 2010. In this year, the Interpretation of the Supreme People's Court of Several Issues on the Specific Application of Law in the Handling of Criminal Cases about Illegal Fundraising was issued. ${ }^{41}$ The Interpretation sets out four features of 'absorbing public savings illegally or in disguised form'. ${ }^{42}$ These four features include: 1) absorbing funds without the legal approval of the relevant department or under the disguise of lawful business operations; 2) absorbing funds from the general public, i.e. unspecified people; 3) promising to repay the principal and interests or make payments in the form of currency, real objects, equities, etc. within a certain time limit; and 4) publicising by means of media, recommendation fairs, leaflets, mobile phone text messages and so on. Further, there is an exhaustive list of 11 specific types of illegal fundraising. ${ }^{43}$ In addition, the Interpretation sets out the extent of adverse impact that will lead to criminal liability and what will constitute a 'more serious offence' to justify heavier penalties. ${ }^{44}$

\footnotetext{
${ }^{36}$ See $n 6$ above.

${ }^{37}$ Cynthia Schultz, 'Economic Crimes in the People's Republic of China: A Swinging Door Policy' (1989) 5 American University International Law Review 161.

${ }^{38}$ The law was adopted at the 13th Meeting of the Standing Committee of the Eighth National People's Congress on 10 May 1995. It was subsequently revised by the 6th Meeting of the Standing Committee of the Tenth National People's Congress on 27 December 2003.

${ }^{39}$ Art 79 of the 1995 law; Art 81 of the 2003 law.

${ }^{40}$ Art 176 of the Criminal Law. The Criminal Law of China was adopted by the Second Session of the Fifth National People's Congress on 1 July 1979 and revised by the Fifth Session of the Eighth National People's Congress on 14 March 1997; the most recent ninth amendments were done in 2015.

${ }^{41}$ Interpretation No.18 (2010) of the Supreme People's Court.

${ }^{42}$ Art 1 of the Interpretation. These four features must all be met to establish an offence. For example, it is acceptable to absorb funds from relatives, friends or specific person within an entity without publicity in the society.

${ }^{43}$ Art 2 of the Interpretation.

${ }^{44}$ A criminal offence in this regard will involve: i) funds of over RMB 200,000 million for an individual offender (or RMB 1 million for an enterprise offender); or ii) over 30 victims (or 150 for an enterprise case); or iii) causing economic loss of over RMB 100,000 (or RMB 500,000 for an enterprise case). For a more serious
} 
In relation to the first feature of illegal fundraising on approval, on the face of it, it is the normal business of commercial banks to absorb public deposits. ${ }^{45}$ In China, all commercial banks must be approved by the CBRC. ${ }^{46}$ There is a minimum capital requirement. ${ }^{47}$ Depending on the nature of the bank, concerning whether it is operating at a national level, city level or village level, the amount can range from RMB 1 billion to RMB 50 million. Alternatively, it is possible for companies to issue shares to, and therefore raise funds from the public. Similarly, a public issue must be approved by the CSRC. ${ }^{48}$ As a basic requirement, issuers are expected to have sustainable profitability and sound financial position. ${ }^{49}$ Once approved, shares can be issued to unspecified objects or more than 200 specified objects. A public issue without the necessary approval can lead to criminal sanctions. ${ }^{50}$ Even in a smaller company (or investment scheme) which does not involve the public, it may still constitute a criminal offence if fraud is involved or the operation is simply regarded as illegal. ${ }^{51}$ The former could lead to death penalty. ${ }^{52}$ Owing to the difficulty to prove the intention to defraud, it is observed that the courts seem to favour certain high status offenders by charging them with the less severe crime of illegal fundraising, as opposed to fundraising fraud. ${ }^{53}$ In other words, there is an element of arbitrariness in deciding what charge to bring. One notable example will be the $W u$ Ying case. ${ }^{54} \mathrm{Wu}$ Ying was initially charged with illegal fundraising, but the charge later escalated to fundraising fraud. It is suggested that Wu Ying's peasant family background may have contributed to the escalation of charge. ${ }^{55}$ Furthermore, the case was intended to be a high profile example to deter further emerging private finance. ${ }^{56}$ In 2007, Wu Ying was arrested by the police for raising RMB 770 million from 11 people, with high interest rates promised. On the face of it, the case should not entail illegal fundraising as she did not raise funds from the general public.

This relates to the second feature about the involvement of the public. It is echoed by other financial rules and regulations. ${ }^{57} 200$ is a notable number to define the word 'public'. Article

offence, it will involve: i) funds of over RMB 1 million for an individual offender (or RMB 5 million for an enterprise offender); or ii) over 100 victims (or 500 for an enterprise case); or iii) causing economic loss of over RMB 500,000 (or RMB 2.5 million for an enterprise case).

${ }^{45}$ Art 3 of the Law on Commercial Banks 2003.

${ }^{46}$ Ibid. Art 16.

${ }^{47}$ Ibid. Art 13.

${ }^{48}$ Art 10 of the Chinese Securities Law. This law was adopted at the Sixth Session of the Standing Committee of the Ninth National People's Congress on 29 December 1998; last amended at the Tenth Session of the Standing Committee of the Twelfth National People's Congress on 31 August 2014.

${ }^{49}$ Ibid. Art 13.

${ }^{50}$ Art 179 of the Criminal Law of China.

${ }^{51}$ Ibid. Arts 160, $192 \& 225$. See the texts of the articles which stipulate the relevant penalties.

${ }^{52}$ Ibid. Art 199, before the amendment in 2015.

${ }^{53}$ Hongming Cheng, 'Financial Fraud in China: A Structural Examination of Law and Law Enforcement' in Susan Will et al. (eds) How They Got Away With It: White Collar Criminals and the Financial Meltdown (Columbia University Press, 2012) 304.

${ }^{54}$ Wu Ying (2009) No. 1 Jinhua Intermediate People's Court and (2010) No. 27 Zhejiang Higher People's Court. Arguably, a landmark case on illegal fundraising and has been discussed extensively by literature. See e.g. Xiang Ren, 'Judicial Cases in China in 2012' (2013) 1 Chinese Journal of Comparative Law 409, and Shen Wei, 'Market-Based Regulatory Responses to Private Lending in China: Beyond a Law and Society Paradigm' (2017) 4 Asian Journal of Law and Society 59.

${ }^{55}$ Cheng (n 53) 304.

${ }^{56}$ Yunxin Tu and Qianhong Qin, 'The Real Plight between the Judicature and Public Opinion and its Extrication in terms of Jurisprudence' (2013) 1 China Legal Science 97, 104.

${ }^{57}$ Sub-Committee of Legislative Affairs of the Standing Committee of the National People's Congress and the Legislative Affairs Office of the State Council, 'Determination to Prevent and Combat Illegal Fundraising 
6 of the Interpretation prohibits the issuance of company shares and bonds to unspecified persons or specified group of over 200 people, without approval of the competent authorities, which is reinforced by the aforementioned requirement under the securities law. Similar provision was also found in the Interim Measures for the Administration of Capital Trust of the Trust and Investment Companies ${ }^{58}$, trust and investment companies were not allowed to have over 200 investment contracts at a time. ${ }^{59}$ Despite the fact that the number of 200 can provide some guidance of what can constitute 'the public', there is not a bright line rule in practice. ${ }^{60}$ In the case of Jiang Xuexiu ${ }^{61}$, Jiang was the general manager of Qin Jian Tea Technology Company. The company was incorporated by Jiang and her husband Qin Qishu with a registered capital of RMB 5 million. The line of business was tea cultivation, processing, marketing and production of ceramics for sale. From 2007 to 2009, Qin Jian Company raised RMB 73 million from 345 people. As of the time when Jiang and Qin was convicted of illegal absorbing public savings under Article 176 of the Criminal Law, the victims were only returned RMB 56 million in principal and an interest of RMB 8 million. Jiang and Qin were handed a sentence of imprisonment for six years and five years respectively, together with a fine of RMB 200,000 each. On the face of it, the conviction and the resulting sentence were all done in accordance with the law, which has been discussed above. However, in this case, out of the 345 victims, a number of them were actually the employees of Qian Jian Company, as well as their friends and families. It is dubious if these individuals should constitute the meaning of 'unspecified persons or specified group' under the Interpretation. This can be contrasted to the cases of Xiling District Property Development Company ${ }^{62}$ and Tian Jianzhou ${ }^{63}$. In these two cases, the amount raised from employees was indeed regarded as internal fundraising and was deductible from the overall amount of fundraising when deciding whether or not there was a breach of Article 176.

In relation to the third element of illegal fundraising about return, under the Measures for the Administration of Trust Companies' Trust Plans of Assembled Funds, when recommending a trust plan, a trust company cannot promise in any way that the trust capital would suffer no loss, or guarantee in any way the minimum return of the trust capital. ${ }^{64}$ Similarly, the CSRC has prohibited securities firms from promising their clients, by written or oral, express or implied form, any investment returns. ${ }^{65}$ Any forecast of investment

\footnotetext{
Activities: Q\&A with Xinhua News' [堅決防範和打擊非法集資等違法犯罪活動一全國人大常委會法制工 作委員會和國務院法制辦公室負責人答新華社記者問] (2007).

${ }^{58}$ Order No.7 (2002) of the People's Bank of China. It was repealed by the Measures for the Administration of Trust Companies' Trust Plans of Assembled Funds [No. 3 (2007) of the China Banking Regulatory Commission].

${ }^{59}$ Art 6 of the Interim Measures.

${ }^{60}$ Wei He and Lufeng Wang, 'On the Definition of 'Public' in the Crime of Illegally Absorbing Public Deposits' (2013) 11 Legal Studies [法學] 156.

${ }^{61}$ Jiang Хиехiu (2011) Hunan Baojing County People's Procuratorate.

${ }^{62}$ Xiling District Property Development Company (2001) Hubei Yichang City Xiling District People's Court.

${ }^{63}$ Tian Jianzhou (2009) Henan Anyang City Intermediate People's Court.

${ }^{64}$ Order No.3 (2007) of the China Banking Regulatory Commission. See Art 8(1) of the Measures. The Measures were amended by the Decision of the China Banking Regulatory Commission on Amending the Measures for the Administration of Trust Companies' Trust Plans of Assembled Funds [Order No. 1 (2009) of the China Banking Regulatory Commission].

${ }^{65}$ Circular of China Securities Regulatory Commission on the Relevant Issues Concerning Securities

Companies' Undertaking of the Business of Collectively Entrusted Investment Management [Order No. 107 (2003) of the China Securities Regulatory Commission].
} 
proceeds must be substantiated and for a reference purpose only. Ultimately, all investment risks should be borne by the clients.

As for the final feature about a publicity campaign, the Interim Measures also prohibited the companies to conduct marketing campaigns through newspapers, television, broadcasting or other public media. ${ }^{66}$ Violation of this provision by the trust and investment companies will be regarded as illegal fundraising. Furthermore, as per the Interpretation, any advertising agencies which play a part in the illegal fundraising activities can be criminally liable. ${ }^{67}$

The scale of illegal fundraising activities has attracted the attention of various regulators and government departments. According to the PBOC, in 1998, there were 7,900 illegal fundraising activities involving an amount of RMB 39 billion. ${ }^{68}$ The State Council released the statistics of 2006 revealing 1,999 illegal fundraising activities in the year involving an amount of around RMB 30 billion. ${ }^{69}$ To act in line with the State Council's direction to combat the problem, the Inter-agency Anti-illegal Fundraising Taskforce was established. ${ }^{70}$ According to the Taskforce, the scale and number of the problem has reached record high recently. ${ }^{71}$ In 2015, the number of cases reached 6,000, totalling RMB 250 billion. In the first quarter of 2016 alone, there were 2,300 new cases. President Xi Jinping of China has expressed his concern over the situation. ${ }^{72} \mathrm{He}$ was particularly concerned about using efinance to disguise illegal fundraising in recent cases of Ezubao and Zhongjin, which caused substantial financial loss to the public and disrupted market order.

\section{A. Ezubao}

Established in 2014, Ezubao was one of China's highest-profile peer-to-peer lending sites, promising investors annual returns of up to 15 per cent. According to the estimate of the Financial Times, RMB 50 billion was involved in the company's 'Ponzi scheme', affecting 900,000 investors. ${ }^{73}$ Ezubao used to be the star of the financial investment platforms in China, moving an approximate RMB 800 million a day, amidst the competition from more than 3,000 similar operations. ${ }^{74}$ Ezubao claimed to be a peer-to-peer lender, matching investors with potential borrowers over the Internet. The legal consideration of this is that, as a middleman, they were not raising funds themselves per se, but just for other borrowers, as a way to get around the Criminal Law. These products offered investors annual interest payments of 9 to 14.6 per cent. However, most of the investment products the company

\footnotetext{
${ }^{66}$ Art 4(5) of the Interim Measures.

${ }^{67}$ Art 8 of the Interpretation and Art 222 of the Criminal Law.

${ }^{68}$ Notice of the People's Bank of China to Further Combat Illegal Fundraising Activities [Order No. 289 (1999) of the People's Bank of China].

${ }^{69}$ Notice of the General Office of the State Council on Issues concerning Severely Punishing Illegal Funds Raising According to Law [Order No. 34 (2007) of the General Office of the State Council].

${ }^{70}$ China Banking Regulatory Commission, 'CBRC Officials Answered Questions on Anti-illegal Fund-raising' (2013) <http://www.cbrc.gov.cn/EngdocView.do?docID=B031026DB58947299C773504ACF79043>.

${ }^{71}$ Caixin, 'The Scale of Illegal Fundraising Reached a Peak in 2015' [2015 年非法集資案件達歷史最高峰值] (2016) <http://finance.caixin.com/2016-04-27/100937395.html>.

${ }^{72}$ In a speech by President Xi at a Symposium on Cybersecurity and IT Application on 19 April 2016.

${ }^{73}$ Tom Mitchell, 'Arrests in China over \$7.6bn Ponzi Scheme’ Financial Times (1 February 2016).

${ }^{74}$ Aladdin Rillo and Valdimir dela Cruz, 'The Development Dimension of E-Commerce in Asia: Opportunities and Challenges' (2016) ADBI Policy Brief No. 2016-2

<https://www.adb.org/sites/default/files/publication/185050/adbi-pb2016-2.pdf>.
} 
marketed were fake. The investment platform was primarily used to enrich top executives. ${ }^{75}$ That included more than RMB 1 billion, that Ding Ning, the company's 34-year-old founder, is reported to have spent on items and gifts including real estate, cars and luxury goods. Further, the salary paid to Ding's brother, Ding Dian, was increased to RMB 1 million a month from RMB 18,000. The company spent as much as RMB 800 million on payroll in a month. Xinhua News first reported the enforcement action against the company by the police in December $2015 .^{76}$ Chinese police have arrested more than 20 people. The Chinese police has taken the unprecedented step to start a web portal to collect evidence from the victims so as to facilitate their investigation. ${ }^{77}$ Following the investigation, Beijing People's Procuratorate in December 2016 filed charges of fraudulent fundraising ${ }^{78}$ against Ezubao's parent companies, Yucheng Holdings and Yucheng Global, and ten people. A further 16 individuals were charged with illegally absorbing public deposits ${ }^{79}$.

\section{B. Zhongjin}

Zhongjin, a Shanghai-based investment firm, was another Ponzi scheme, which was selfconfessed outright by its founder on state television. ${ }^{80}$ Zhongjin Capital Management was established by Xu Qin in 2012, with a registered capital of RMB 10 million. It was reported that the firm had raised funds illegally from 25,000 investors involving a sum of almost RMB 40 billion. Xu, together with 35 executives, were arrested in 2016 by the Shanghai police for illegal fundraising. In the beginning, Zhongjin would promise a monthly return of 2 per cent and quickly amassed RMB 50 million. To build up a premium corporate brand, the firm set up offices in high end commercial buildings like Jin Mao Tower and Shanghai World Financial Centre. Meanwhile, the firm's promised return increased to 10 to 25 per cent or even up to 400 per cent. Owing to the nature of its business as an investment firm, it was subject to the regulation of the Securities Investment Fund Law. ${ }^{81}$ Quite consistent to a point made before, Article 51 of the law stipulates that the public offering of a fund must be registered with the securities regulatory authority of the State Council. Otherwise, according to Article 88, a private fund should not be offered to more than 200 investors. Indeed, additional constrains are present if the fund is operating in a corporate form or a partnership form, which means that the investor will be either a shareholder or a partner of the firm, as opposed to a client. According to the Chinese Company Law, the number of shareholders in a limited liability company is limited to 50 only. ${ }^{82}$ Likewise, a limited liability partnership can only have up to 50 members. ${ }^{83}$ To get around all these requirements, $\mathrm{Xu}$ established more

\footnotetext{
${ }^{75}$ Neil Gough, 'Online Lender Ezubao Took \$7.6 Billion in Ponzi Scheme, China Says' New York Times (1 February 2016).

${ }^{76}$ Xinhua News, 'Ezubao under Criminal Investigation’ ['e 租寶’涉嫌違法犯罪正在接受調查] (2015) <http://news.xinhuanet.com/legal/2015-12/12/c_1117439759.htm>.

${ }^{77}$ Ministry of Public Security, 'Ministry of Public Security Opened Investor Information Registration Platform for Illegal Investment Cases; First for Ezubao’ [公安部開通非法集資案件投資人信息登記平台 首對“ $\mathrm{e}$ 租寶” 案件投資人開放] (2016) <http://ecidcwc.mps.gov.cn/port/archiveView?id=10>.

${ }^{78}$ Art 192 of the Criminal Law of China.

${ }^{79}$ Ibid. Art 176.

${ }^{80}$ Reuters, 'China Wealth Management Firm Executive Confesses to Ponzi Scheme' (2016) <http://www.reuters.com/article/us-china-wealth-arrests-idUSKCNOY71AK>.

${ }^{81}$ The Securities Investment Fund Law of the People's Republic of China was adopted at the 5th Session of the Standing Committee of the Tenth National People's Congress on 28 October 2003; last revised at the 14th meeting of the Standing Committee of the Twelfth National People's Congress on 24 April 2015.

${ }^{82}$ Art 24 of the Company Law.

${ }^{83}$ Art 61 of the Law of the People's Republic of China on Partnerships. It was adopted at the 24th Meeting of the Standing Committee of the Eighth National People's Congress on 23 February 1997 and amended at the 23rd Meeting of the Standing Committee of the Tenth National People's Congress on 27 August 2006.
} 
than 200 affiliated companies to accommodate the rapid expansion of his firm. All the returns from these companies came almost solely from the contribution from the investors. Coupled with the lavish lifestyle of $\mathrm{Xu}$, who reportedly spent RMB 500 million of the investors' money, the demise of the firm appeared inevitable.

\section{What Makes the Problem so Prevalent?}

The phenomenon of 'credit intermediation involving entities and activities outside the regular banking system' is generally known as 'shadow banking'. ${ }^{84}$ This is a concern because it is regarded as a source of 'systemic risk or regulatory arbitrage'. ${ }^{85}$ Being outside the formal banking sector generally means they lack a strong safety net, such as publicly guaranteed deposit insurance or lender of last resort facilities from central banks, and operate with a different, and usually lesser, level of regulatory oversight. ${ }^{86}$ These characteristics increase the risks for financial stability, which justifies the need for regulation. The primary role of a functional financial system is the allocation of ownership of the economy's capital stock. ${ }^{87}$ The market is a developed system which creates information about investment projects and can therefore guide investors' funds to better uses. ${ }^{88}$ Specialisation, as well as acquisition and dissemination of information, is encouraged to reduce the cost of aggregating dispersed savings, thereby facilitating investment. ${ }^{89}$ Different modes of finance may serve different purposes. It is thought that in the presence of asymmetric information, banks generally finance only well-established, safe borrowers, while stock markets can encourage more risky, productive and innovative projects. ${ }^{90} \mathrm{~A}$ notable advantage of bank finance over a stock market is, the latter is only accessible by large companies only, when a loan from banks is in principle accessible to everyone.

In 1949, when the communist government came to power, stock exchanges were viewed as one of the most prominent symbols of an oppressive capitalist regime and were forced to close down. State-owned banks have since become the sole representatives of the financial sector in the country. Banks still intermediate nearly 75 per cent of the capital in China, a significantly higher proportion than in other Asian countries (43 per cent in India, 35 per cent in Japan and 33 per cent in South Korea) and the US (only 19 per cent). ${ }^{91}$ However, the banking sector in China has suffered from various problems, notably non-performing loans. This problem of the Chinese bank-centred system can be explained by several factors. First, state-controlled banks have continued to account for 83 per cent of bank assets in China since the new millennium. ${ }^{92}$ The state ownership of banks has reduced competition and lessened

\footnotetext{
${ }^{84}$ Financial Stability Board, 'Global Shadow Banking Monitoring Report 2016' (2017)

<http://www.fsb.org/2017/05/fsb-publishes-global-shadow-banking-monitoring-report-2016>.

${ }^{85}$ People's Bank of China, 'China: Financial Stability Report 2013' (2013).

${ }^{86}$ Douglas Elliott et al., 'Shadow Banking in China: A Primer' (2015) The Brookings Institution Research Paper <https://www.brookings.edu/wp-content/uploads/2016/06/shadow_banking_china_elliott_kroeber_yu.pdf>.

${ }^{87}$ Eugene Fama, 'Efficient Capital Markets: A Review of Theory and Empirical Work' (1970) 25 Journal of Finance 383.

${ }^{88}$ Raymond Atje and Boyan Jovanovic, 'Stock Markets and Development' (1993) 37 European Economic Review 632.

${ }^{89}$ Philip Arestis et al., 'Financial Development and Economic Growth: The Role of Stock Markets' (2001) 33 Journal of Money, Credit and Banking 16, 18.

${ }^{90}$ Guglielmo Caporale et al., 'Stock Market Development and Economic Growth: the Causal Linkage' (2004)

29 Journal of Economic Development 33, 36.

${ }^{91}$ McKinsey Global Institute, 'Mapping Global Capital Markets Fourth Annual Report' (2008) <http://www.mckinsey.com/mgi/publications> 19.

92 McKinsey Global Institute, 'Putting China's Capital to Work: The Value of Financial System Reform' (2006) $<$ http://www.mckinsey.com/mgi/publications > 35 .
} 
the pressure on banks to operate on a commercial, profit-oriented basis. Second, there is a lack of good internal credit assessment capabilities in many banks. The reason behind most of the non-performing loans in the past was the directed lending policies of the government to fund state-owned enterprises (SOEs) regardless of their profitability. Third, these state-owned banks have a decentralised structure. Lending decisions are made at the local branch level, which is susceptible to influence from local government and favouritism towards local SOEs. This diffuse structure of banks and many SOEs makes it difficult for banks to collect and share useful information to make an informed lending decision.

SOEs are favoured for a variety of reasons, including: implicit state guarantees; favoured market positions for some SOEs that make them better credit risks; internal reward and punishment systems that mean a failed loan to an SOE is unlikely to be punished severely while bad loans to the private sector can lead to job loss; social/career considerations that make lending to entities run by powerful Party members attractive; and even direct pressure from party or state officials. ${ }^{93}$ In other words, it is dubious if individuals and/or small and medium-sized enterprises can get money from banks easily.

According to the World Bank's Doing Business project, which provides objective measures of business regulations and their enforcement across 190 economies, China ranks 62 in the aspect of getting credit in 2017. ${ }^{94}$ In Shanghai, 91.1 per cent of individuals and firms are listed in a public credit registry with information on their borrowing history from the past 5 years, enabling lenders to make an informed lending decision. This is very high, compared to an East Asia and Pacific average of 14.7 per cent and an OECD high income country average of 12.1 per cent. By contrast, the story is quite different when considering the degree to which collateral and bankruptcy laws protect the rights of borrowers and lenders. China just has a score of 4 in the strength of legal rights index, as opposed to an average of 6.6 and 6 for the East Asia and Pacific region, and OECD high income countries respectively. Weak legal rights can make borrowers more reluctant to borrow, and lenders more reluctant to lend.

Viable fundraising channels must be in place to ensure the survival of emerging private economic activities. The process of economic liberalisation in China started when the communist party began to focus their work on 'social modernisation' in 1979 and recognised that China's economy had underperformed for many years. ${ }^{95}$ The most important aspect of modernisation was the change in policy away from the state's control of the economy and towards the gradual recognition of the role of private companies. Accessing credit remains a significant obstacle for Chinese companies. As of the end of 2006, according to the World Bank, smaller businesses, which contributed some 60 per cent of China's GDP, accounted for only 15 per cent of outstanding credit, most of which was from banks. ${ }^{96}$ Fast-forwarding almost 10 years to 2015, loans offered by banks to smaller businesses increased to 23.6 per cent of the total amount, when their share of the national economy was roughly the same as before. ${ }^{97}$ The weaknesses in China's financial sector motivated businesses, especially small

\footnotetext{
${ }^{93}$ Elliott et al. (n 86) 6.

${ }^{94}$ World Bank, 'Doing Business 2017' (2017) <http://www.doingbusiness.org>.

95 Iain MacNeil, 'Adaptation and Convergence in Corporate Governance: The Case of Chinese Listed

Companies' (2002) 2 Journal of Corporate Law Studies 289, 297.

${ }^{96}$ World Bank, Doing Business in China (World Bank, 2008) 18.

${ }^{97}$ Mintai Institute of Finance and Banking, 'China MSME Finance Report 2016' (2016)

$<$ https://smefinanceforum.org/post/china-msme-finance-report-2016> and Muyuan Cai, 'SMEs an Important

Force for Economic Growth’ China Daily (2 March 2015) <http://www.chinadaily.com.cn/bizchina/2015-

03/02/content_19696335.htm>.
} 
and medium-sized enterprises, to rely on their own savings (profits) to finance their operation. $^{98}$

On the face of it, there is still a range of financing channels available to these companies. ${ }^{99}$ They can get money from a variety of banking institutions and quasi-financial institutions, such as postal savings bank, large commercial banks, credit cooperatives, micro-credit companies, venture capital, etc. ${ }^{100}$ Companies can also seek a listing on the stock exchanges, when the Growth Enterprise Board (ChiNext) and Small and Medium Enterprise Board provide a lower listing requirement than the main boards. ${ }^{101}$ Finally, there is also 'informal finance', which is defined as 'unconventional lending between enterprises, or between enterprises and individuals'. ${ }^{102}$ According to the IMF, the scale of total social financing (less bank loans, equity-like items, and bond issuance) was around RMB 20 trillion in 2014, around 35 per cent of the year's GDP. ${ }^{103}$

Awrey observes that there has been an increasingly important segment of the Chinese shadow banking system: USD 2 trillion dollar market for wealth management products (WMPs). ${ }^{104}$ WMPs are a form of collective investment vehicle that raises large pools of capital from multiple investors in exchange for the issuance of financial claims.

WMPs possess a number of distinctive legal and economic features. First, despite being marketed by the financial institutions as substitutes for conventional deposit accounts, the liabilities generated by the majority of these products do not reside on bank balance sheets. Second, while WMPs typically lock-in investors' capital for relatively short periods of time, this capital is often invested into less liquid, longer-term assets. The resulting maturity and liquidity mismatches thus recreate the fragile capital structure of banks. Third, WMPs have emerged largely in response to China's interventionist approach toward both banking regulation and broader macroeconomic policy. ${ }^{105}$

This trend may echo the Zhongjin case, when the company has marketed itself as in the industry of capital management. The dramatic growth of WMPs can be attributed to several reasons. ${ }^{106}$ WMPs are not legally characterised as deposits and are, accordingly, exempt from certain PBOC's requirements. Second, they provide a means the financial institutions of shifting unwanted assets off their balance sheets, by using capital raised in the WMPs to purchase its own unwanted loans or other assets. Third, the term structure of WMPs is often designed to ensure ostensible compliance with both the CBRC's and the PBOC's requirements, if it needs to be. According to Awrey, the emergence and growth of WMPs can

\footnotetext{
98 This is the conclusion from Allen and colleagues, according to their investigation of China's financing channels over the period of 1994 to 2002. See Franklin Allen et al., 'Law, Finance, and Economic Growth in China' (2005) 77 Journal of Financial Economics 57, 79; and Dennis Yang et al., 'Why Are Saving Rates so High in China?' (2011) IZA Discussion Paper No. 5465 <http://ftp.iza.org/dp5465.pdf>.

${ }^{99}$ Mintai Institute of Finance and Banking (n 97).

${ }^{100}$ For a full range of recognised financial institutions, see the Notice of the People's Bank of China on Issuing the Coding Standards for Financial Institutions [Order No.363 (2009) of the People's Bank of China].

${ }^{101}$ For an in-depth analysis of the former, see Horace Yeung, 'Just Another Casino? The Case of Launching the Growth Enterprise Board in China' (2010) 21 International Company and Commercial Law Review 68.

${ }^{102}$ Mintai Institute of Finance and Banking (n 97).

${ }^{103}$ IMF, 'Global Financial Stability Report' (2014).

${ }^{104}$ Dan Awrey, 'Law and Finance in the Chinese Shadow Banking System' (2015) 48 Cornell International Law Journal 1.

105 Ibid. 4-5.

${ }^{106}$ Ibid. 33.
} 
be regarded as a private contractual response to changes in the constraints imposed by various forms of public regulatory intervention. ${ }^{107}$ In other words, WMPs are designed to occupy the negative legal space created by the existence of public regulatory intervention elsewhere within the financial system. Unless Chinese regulators take action to close existing loopholes and address the risks posed by WMPs, further contractual innovations like WMPs will continue to exist.

Similarly, the case of Ezubao raises the concern of the legitimacy of P2P lending platforms. China's P2P lending industry recorded transactions valued at USD 445 billion in 2017, comparable to around what China's banks lent in one month. ${ }^{108}$ Meanwhile, of more than 6,000 online lending platforms launched over the past several years, fewer than 2,000 were still remaining in 2018. ${ }^{109}$ Commentators attribute this to regulation, competition and fraud. Whilst the case of Ezubao may point to how fraud can thin the industry and consumers are getting sceptical about the integrity of platforms, there is also an important question of legality. As mentioned before, those involved in running Ezubao were convicted of fraudulent fundraising or illegally absorbing deposits. According to Chaffee and Rapp, P2P lending shares all of the risks associated with traditional 'brick and mortar' lending including lending fraud, identity theft, money laundering, consumer privacy and dataprotection violations, and terrorism financing. ${ }^{110}$ These risks are then married to and amplified by the anonymity and ubiquity of the Internet. Shen observed that China had no specific laws regulating P2P lending, apart from the provisions surrounding illegal fundraising as discussed above spanning across different laws and regulatory instruments. ${ }^{111}$ He further indicated that $\mathrm{P} 2 \mathrm{P}$ lending platforms had long been removed from the regulatory space of the CSRC, CBRC and PBOC. ${ }^{112}$ The CSRC oversees entities that issue securities and futures, but since P2P lending does not involve the issuance of securities, it is not within the CSRC regulatory mandate. The CBRC, on the other hand, oversees banking institutions when P2P lending is strictly not one of them. Furthermore, P2P lending also bypasses the PBOC's regulations on financial markets because P2P platforms do not rely on the central bank's lending of last resort. Nevertheless, with China's rapidly developing markets and legal system, Shen's observation is inevitably outdated. The Interim Administrative Measures for the Business Activities of P2P Lending Information Intermediaries was enacted on 17 August 2016 by the CBRC, conjoint with other authorities. ${ }^{113}$ The Interim Measures consist of eight chapters with a total of 47 articles. In the view of You, the new regulatory regime represents a pivotal change leading to a regulatory paradigm shift from light regulation to tight regulation. ${ }^{114}$ The Interim Measures refine entry conditions for players in the P2P lending market. More importantly, the Interim Measures adopt several regulatory approaches to mitigate potential risks, including a multifurcate regulatory structure, negative list

\footnotetext{
107 Ibid. 37.

${ }^{108}$ Emily Feng, 'China's P2P Lenders Brace for Renewed Regulatory Crackdown' Financial Times (2 April 2018).

${ }^{114}$ Chuanman You, 'Recent Development of FinTech Regulation in China: A Focus on the New Regulatory Regime for the P2P Lending (Loan-based Crowdfunding) Market' (2018) 13 Capital Markets Law Journal 85.
} 
management, information disclosure requirements and third-party-based monitoring. The compliance requirements may prove to be difficult for many of the existing P2P lending platforms, but will provide clarity for those strong enough to stay.

Other the demand side factors, the supply side factors can also play their role. As said, a financial system is an institution to allocate resources and thereby enable economic growth. Chinese households tend to have a higher saving rate than those in the Western world. ${ }^{115} \mathrm{~A}$ key to channel these savings to the entrepreneurs, who are capital hungry, is to ensure there are sufficient investment options, which are indeed fairly limited currently. ${ }^{116}$ After the interest rate liberalisation in China, interest rates for deposits and loans are essentially the market rates, but no longer set by the PBOC. ${ }^{117}$ After the recent financial crisis when interests rates have been hitting an all-time low, this means that savers would get a measly return by putting their in a typical saving account. Stock market is an option but the press describes the behaviour of Chinese investors as 'betting' or putting stock in 'Lady Luck' ${ }^{118}$ Investing legend Warren Buffett has famously referred to the Chinese stock markets as 'casino'. ${ }^{119}$ This prompts people to go to the real estate market, driving up the property price in major Chinese cities to record high. For example, homes in Shenzhen were sold at an average of RMB 49,259 per square meter (or USD 690 a square foot), in April 2016, as much as the Rockridge neighborhood in Oakland in the US, a pricey part of the San Francisco Bay Area, where home prices averaged USD 704 a square foot. ${ }^{120}$

In light of these demand and supply side factors, the need to diversify and deepen China's fundraising channels becomes apparent. The question will be how to formalise and properly regulate those channels.

\section{How Should Regulation Address the Problem?}

The market as an invisible hand guides participants in well-functioning market economies to allocate resources in ways that achieve economically efficient outcome. The starting point of regulation is that there is no need to regulate unless there is a failure of markets. ${ }^{121}$ Historically, the idea of investor protection stemmed from the risk of fraudulent or opportunities behaviour in the financial markets, making a case of a body of rules, commonly referred to as 'securities law' or 'securities regulation' to exist. ${ }^{122}$ There are various considerations in determining an appropriate level of regulation. ${ }^{123}$ Firstly, what is the nature and extent of any market failures? Analysis of securities regulation often starts from the assumption that its ultimate goal is to attain efficient financial markets. An efficient market is

\footnotetext{
${ }^{115}$ Neelabh Chaturvedi, 'Just How Much does China Save vs the Rest of World?' CNBC (25 October 2015) <http://www.cnbc.com/2015/10/25/china-savings-rate-versus-the-world-in-a-chart.html>.

${ }^{116}$ Chi Lo, China after the Subprime Crisis: Opportunities in the New Economic Landscape (Palgrave Macmillan, 2010) 145.

${ }^{117}$ Grace Zhu, 'Interest Rate Liberalization - With Chinese Characteristics' WSJ (18 May 2015) <https://blogs.wsj.com/chinarealtime/2015/05/18/interest-rate-liberalization-with-chinese-characteristics>.

${ }^{118}$ See Tom Mitchell and Justine Lau, 'Investors are Betting on Chinese IPOs' Financial Times (31 May 2006) and Richard McGregor, 'Chinese Put Stock in Lady Luck' Financial Times (12 May 2007). 'With Chinese IPOs you have to ride the momentum, as long as you get out before it becomes too expensive, you will be fine,' said Yang Liu, a China fund manager at Atlantis Investment Management.

${ }^{119}$ Evelyn Cheng, 'Buffett Warns China that Markets can Sometimes Become a "Casino"' CNBC (6 May 2017) <http://www.cnbc.com/2017/05/06/buffett-warns-china-that-markets-can-sometimes-become-a-casino.html>.

${ }^{120}$ Yuan Li, 'How Shenzhen Mimics Silicon Valley' WSJ (1 June 2016).

${ }^{121}$ Armour et al. (n 24) 51.

122 John Armour et al., Anatomy of Corporate Law (OUP, 2017) 243.

${ }^{123}$ Armour et al. (n 24) 52.
} 
one in which prices always fully reflect the available information. ${ }^{124}$ The general idea is, the lower the cost of information distribution, the more efficient the market will be. Securities regulations are intended to reduce the cost of gathering, verifying and pricing information. ${ }^{125}$ A second step is to determine the regulatory interventions required. Apart from disclosure duties, restrictions on fraud and manipulation can reduce information cost by placing the burden of verifying the information on the information source. ${ }^{126}$ In the US, Federal intervention in the 1930s was justified by a contention of market failure. ${ }^{127}$ First, the market failed to protect investors from stock price manipulation and fraud. Second, it produced an inadequate level of corporate disclosure. The Securities Act of 1933 and the Securities Exchange Act of 1934 were concerned with the disclosure requirement as well as the prevention of market manipulation and insider trading. A final step is an evaluation of such remedial intervention to see whether an alternative remedy needs to be sought.

Traditionally, Chinese attitude to financial regulation has been more like 'crash-then-law' or 'growth-then-law'. ${ }^{128}$ For example, the Chinese stock markets had been established in the beginning of 1990s, but the first set of securities law in China did not come out until 1998. It is not to say this pattern is unique in China. Such a pattern of legal change is also witnessed in the US. ${ }^{129}$ It is also worth noting that China has a conservative stance in regulating the financial markets. In the early days of the Chinese stock market, the CSRC imposed a quota on the maximum number of shares that could be issued each year. Its intention was to curb the potentially excessive investment demand in a pre-mature market, where market participants had not developed an understanding of the market rules and their rights and obligations. ${ }^{130}$ Hence, it is not surprising to see China to conduct a similar approach in regulating alternative finance in line with their pragmatic process of economic reform, famously put by the legendary Chinese leader Deng Xiaoping as 'crossing the river by feeling each stone'. ${ }^{131}$

As mentioned before, China has largely relied on existing laws, most notably, securities law and criminal law to regulate the emergence of alternative finance. Meanwhile, adjustments to regulation have been achieved by piecemeal rules and other rules issued by judiciaries and regulators. In relation to existing laws, there has been a call for the decriminalisation of the

\footnotetext{
${ }^{124}$ The most authoritative definition was given by Fama in 1970, see Fama (n 87). The rise of behavioural finance now casts doubt on some of the assumptions made in the Efficient Capital Market Hypothesis and therefore the market regulatory approach. See, for example, Donald Langevoort, 'Taming the Animal Spirits of the Stock Markets: A Behavioral Approach to Securities Regulation' in John Armour and Joseph McCahery (eds.) After Enron: Improving Corporate Law and Modernising Securities Regulation in Europe and the US (Hart, 2006).

${ }^{125}$ Zohar Goshen and Gideon Parchomovsky, 'The Essential Role of Securities Regulation' (2006) 55 Duke Law Journal 711, 737.

${ }^{126}$ Ibid. 741.

${ }^{127}$ Roberta Romano, 'Empowering Investors: A Market Approach to Securities Regulation' (1998) 107 Yale Law Journal 2359, 2367. The framework of securities legislation in the US consists of seven related but separate statutes that are administered by the Securities and Exchange Commission.

${ }^{128}$ Zhiwu Chen, 'Capital Markets and Legal Development: The China Case' (2003) 14 China Economic Review 451.

${ }^{129}$ John Coffee, 'The Rise of Dispersed Ownership: The Roles of Law and the State in the Separation of Ownership and Control' (2001) 111 Yale Law Journal 1.

${ }^{130}$ China Securities Regulatory Commission, China Capital Markets Development Report (China Financial Publishing, 2008) 165-166.

${ }^{131}$ Xinhua News, 'The Origin of “Crossing the River by Feeling Each Stone”” [“摸著石頭過河”改革方法的來 龍去脈] (2014) < http://dangshi.people.com.cn/n/2014/0409/c85037-24858259.html>.
} 
offence of illegal fundraising, in the absence of frauds. ${ }^{132}$ Although in other overseas markets, it is not uncommon to see criminal liabilities for financial or economic crimes, those crimes normally come with a fraudulent intent. In the US, Bernie Madoff conned his investors out of USD 65 billion. He was finally convicted of violations of the anti-fraud provisions of the Securities Act of 1933, the Securities Exchange Act of 1934 and the Investment Advisers Act of 1940, together with other charges of money laundering, perjury and theft, and received a sentence of 150 years in federal prison. ${ }^{133}$ In the UK, there is a distinction of fraudulent trading and wrongful trading. ${ }^{134}$ Only when a business is carried on with intent to defraud creditors or for any fraudulent purpose, the parties commit a criminal offence, and are subject to imprisonment up to ten years and/or a fine. Otherwise, if the parties are just negligent in carrying on trading when they should know there is no reasonable prospect to turn things around, there will only be a civil liability. Such a dual criminal and civil regime can be a model for China that Article 176 about illegally absorbing public deposits should be removed from the criminal law but Article 192 which concerns financial frauds can be retained. However, it is worth noting that there is a need to show negligence for wrongful trading in the UK but Article 176 is more like a strict liability, in a sense that a party is liable when certain thresholds are met in the course of fundraising. A more similar rule in the UK is perhaps the criminal sanction of making a public offer unless accompanied by an approved prospectus. ${ }^{135}$ There is no way a non-public company can get such an approved prospectus. Indeed, it is not unique in China that a threshold is set to distinguish between a public offer and a private placement. In the past there was a threshold of 50 people in the UK, below which shares were not deemed to be offered to the public. ${ }^{136}$ However, now the Financial Services and Markets Act does not give a clear answer as to what constitutes an offer to the public. ${ }^{137}$ The trace of such an approach is still seen in Hong Kong, for example, a private company can only have a maximum of 50 shareholders. ${ }^{138}$ As discussed, such a requirement is also seen in China.

A parallel controversial point about illegal fundraising has been, whether economic/financial crimes should lead to a death penalty. ${ }^{139}$ Despite the law on illegal fundraising was not formalised until 1995, the conviction and sentenced to death in 1994 of Shen Taifu, then president of Great Wall Electrical and Mechanical Technology Industry Company, had catalysed the legislative process and is widely regarded as the 'first case of illegal fundraising,. ${ }^{140}$ Owing to the absence of relevant law at that time, Shen was convicted of corruption and bribery, instead of illegally raising RMB 1.37 billion per se. Since then, with the introduction of illegal fundraising as a crime, Shen was not the only one who faced a death sentence. In the Wu Ying case, Wu had initially been handed a death sentence which

\footnotetext{
${ }^{132}$ Unirule Institute of Economic, ‘A Study on the Issue of Crime of Illegal Fundraising and Suggestion' [非法 集資類犯罪的立法反思與建議] (2015); Xinmin Liu, 'On the Decriminalisation of “Illegally Absorbing Public Deposits”” [2012] Jiangsu Social Sciences [江蘇社會科學] 136; Xingyuan Feng, 'Lessen the “Illegal Fund Raising” Type of Crime’ [‘非法集資’類罪䔅須輕罪化] People’s Daily (18 May 2015)

<http://finance.people.com.cn/n/2015/0518/c1004-27013897.html>.

${ }^{133}$ FBI, 'Bernard L. Madoff Pleads Guilty to 11-Count Criminal Information and is Remanded into Custody'

(2009) <https://archives.fbi.gov/archives/newyork/press-releases/2009/nyfo031209.htm>.

${ }^{134}$ Sections 213-214 of the Insolvency Act 1986.

${ }^{135}$ Section 755 of the Companies Act 2006.

${ }^{136}$ Brodies LLP, 'Offers of Shares to the Public' (2010) <http://www.brodies.com/node/1475>.

${ }^{137}$ Section 102B of the Financial Services and Markets Act 2000.

${ }^{138}$ Section 11 of the Hong Kong Companies Ordinance (Cap. 622).

${ }^{139}$ Unirule Institute of Economic (n 132). See also Roger Hood, 'Abolition of the Death Penalty: China in

World Perspective’ (2009) 1 City University of Hong Kong Law Review 1, 20.

${ }^{140}$ Unirule Institute of Economic (n 132).
} 
was later suspended. ${ }^{141}$ In another high profile case decided roughly at the same time, Zeng Chengjie was not as fortunate. ${ }^{142}$ Zeng allegedly raised RMB 3.5 billion from more than 20,000 people, and was convicted of illegal fundraising. The case of Zeng Chengjie sparked public outrage because Zeng was executed without his family being notified. This was widely criticised as 'inhuman' and 'cold', even in a country used to capital punishment. ${ }^{143}$ According to the Cornell Centre on the Death Penalty Worldwide, the number of executions in China (for all crimes, not just illegal fundraising) has been declining since 2007. ${ }^{144}$ However, according to Amnesty International's new annual report on capital punishment, China still executed more people than the rest of the world combined in $2017 .{ }^{145}$ According to a survey of 455 criminal justice practitioners in China, as high as 91 per cent supported the death penalty in general. ${ }^{146}$ Meanwhile, the majority did not support the use of the death penalty for economic offences. ${ }^{147}$

There is certainly an inclination in China to shy away from death penalties. As a signatory of the International Covenant on Civil and Political Rights, China has an obligation to uphold its Article 6, whereas 'in countries which have not abolished the death penalty, sentence of death may be imposed only for the most serious crimes', which is largely reflected in Article 48 of the Chinese Criminal Law. China is certainly moving towards this direction, especially in the context of this article, as evidence by its amendments to the Criminal Law in 2011 and 2015. ${ }^{148}$ The Criminal Law originally stipulated that offenders of Articles 192 (illegally fundraising by fraudulent means), 194 (fraudulent activities with financial bills), and 195 (fraudulent activities with letters of credit) who cause extraordinarily heavy losses to the interests of the state and the people shall be sentenced to life imprisonment or death, with forfeiture of property. ${ }^{149}$ The Eighth Amendment of the Criminal Law in 2011 retained the death penalty for Article 192 only. ${ }^{150}$ Then the Ninth Amendment in 2015 further reduced the number of crimes punishable by death from 55 to $46 .{ }^{151}$ The nine crimes previously punishable by death include illegal fundraising by fraudulent means ${ }^{152}$, together with other crimes like smuggling and prostitution. This is an evidence of the Chinese move towards a more liberal approach in regulating illegal fundraising, as well as its criminal law regime

\footnotetext{
${ }^{141}$ Sina News, 'Retrial of the Wu Ying Case' [吳英集資詐騙案重審改判死緩] (21 May 2012) <http://news.sina.com.cn/c/2012-05-21/174824452533.shtml>.

${ }^{142}$ Zeng Chengjie (2013) Hunan Provincial Higher People 's Court.

${ }^{143}$ Mimi Lau, 'Revealed: Truth behind Tragic Secret Execution of Businessman Zeng Chengjie' SCMP (30 July 2013) <http://www.scmp.com/news/china/article/1292842/questions-asked-over-execution-hunan-businessmanzeng-chengjie $>$.

${ }^{144}$ Cornell Centre on the Death Penalty Worldwide, 'Death Penalty Database' (2018)

<https://www.deathpenaltyworldwide.org/country-search-post.cfm?country=China\#f12-2>. In 2007, the Centre estimated 6,500 executions in that year. The figure dropped to around 2,400 in 2015.

${ }^{145}$ Colin Drury, 'China Executes More People than Rest of World Combined, Amnesty Report Reveals' Independent (12 April 2018) <https://www.independent.co.uk/news/world/china-executions-capitalpunishment-death-penalty-state-killing-amnesty-international-a8300726.html>. However, it is worth pointing out that such figures are merely an estimate as the number of executions is kept a state secret in China, despite Article 212 of China's Criminal Procedure Law of 1996 providing for the publication of every execution of a death sentence and all courts have to prepare written records of the execution.

${ }^{146}$ Hood (n 139) 20.

147 Ibid.

${ }^{148}$ National People's Congress, 'Review of the Ninth Amendments to the Criminal Law' [刑法修正案(九)三次 審議歷程回眸] (2015) 〈http://www.npc.gov.cn/npc/xinwen/2015-08/31/content_1945452.htm>.

${ }^{149}$ See Art 199 of the Criminal Law before the Eighth Amendment.

${ }^{150}$ See Art 199 of the Criminal Law before the Ninth Amendment.

${ }^{151}$ G. Huang, 'Death Penalty in China after the Ninth Amendment: Legislatively Abolishing and Judicially Limiting' (2016) 4 Journal of Forensic Science \& Criminology 303.

${ }^{152}$ Art 192 of the Criminal Law.
} 
overall. The Eighth and Ninth Amendments have abolished the death penalty for 13 economic and non-violent crimes and 9 violent crimes respectively. ${ }^{153}$ Zhao and Xu observe that among the ten chapters in the Criminal Law, only 'Chapter IX Crimes of Dereliction of Duty' does not lead to any death penalty. ${ }^{154}$ There are still two crimes punishable by death under 'Chapter III Crimes of Undermining the Order of Socialist Market Economy' (the Chapter of Criminal Law containing economic crimes like illegal fundraising), but both are related to product safety. ${ }^{155}$ Pure financial crimes arguably will not lead to death sentence anymore. However, with 46 capital offences remaining, China still has the highest number of these offences in the world. ${ }^{156}$ In the view of Zhao, China should continue this direction of reducing capital offences. ${ }^{157} \mathrm{He}$ is of the opinion that China should abolish the death penalty for crimes such as embezzlement and bribery. ${ }^{158}$ First, these crimes are non-violent in nature. Second and third, there is no evidence to suggest that the death penalty can deter crimes, and there are indeed alternatives such as life imprisonment.

Other than relying on existing laws, Chinese authorities have tried to use different types of regulatory instruments to implement piecemeal reforms or clarification of existing laws. One example, as discussed extensively before, is the Interpretation of the Supreme People's Court of Several Issues on the Specific Application of Law in the Handling of Criminal Cases about Illegal Fundraising. But fine-tuning a criminal regime is not adequate. Ideally, there should be a dual criminal and civil regime operating. ${ }^{159} \mathrm{~A}$ criminal regime gives public authorities the responsibility to investigate and pursue the offence. In addition to the functions fulfilled by public enforcement, i.e. justice and deterrence, civil remedies can compensate the wronged by allowing the private parties to sue and recoup losses in a court. Private actions are considered as a necessary supplement to public enforcement activities. ${ }^{160}$ In theory, the Chinese Criminal Law has compelled the perpetrators to return all the proceeds to the victims, with the help of the public authorities. Under Article 64 of the law, 'All articles of property illegally obtained by the criminal conduct shall be recovered or he shall be ordered to make restitution or pay compensation for them. The legitimate property of the victims shall be promptly returned.' Furthermore, it is also stipulated in the Securities Law that, where a company unlawfully makes a public offer or does so in any disguised form without approval from the relevant authorities, it will be ordered to cease the issuance and return the funds raised plus interests to the investors. ${ }^{161}$ To facilitate private actions, the Provisions of the Supreme Court on Several Issues concerning the Application of Law in the Trial of Private Lending Cases were issued. ${ }^{162}$ The Provisions are important in several ways. ${ }^{163}$ First,

\footnotetext{
153 Ibid.

${ }^{154}$ Bingzhi Zhao and Wenwen Xu, 'The Ninth Amendments to the Criminal Law: Death Penalty Reform Observation and Reflection’ [刑法修正案(九) 死刑改革的觀察與思考] (2016) Law Application [法律適用] $<$ http://www.iolaw.org.cn/showNews.aspx?id=56519>.

${ }^{155}$ These two crimes are Arts 141 (selling fake medicine) and 144 (selling poisonous or harmful food products).

${ }^{156}$ Bingzhi Zhao, 'Progress and Trend of the Reform of the Death Penalty in China' in Margaret deGuzman and Diane Marie Amann (eds) Arcs of Global Justice: Essays in Honour of William A. Schabas (OUP, 2018) 150151.

157 Ibid.

${ }^{158}$ Ibid. Both are regulated by 'Chapter VIII Graft and Bribery' of the Criminal Law.

${ }^{159}$ John Coffee, 'Law and the Market: The Impact of Enforcement' (2007) 156 University of Pennsylvania Law Review 229, 244.

${ }^{160}$ Harvey Pitt and Karen Shapiro, 'Securities Regulation by Enforcement: A Look Ahead at the Next Decade' (1990) 7 Yale Journal on Regulation 149, 182.

${ }^{161}$ Art 188 of the Securities Law.

${ }^{162}$ Interpretation No. 18 (2015) of the Supreme People's Court.

${ }^{163}$ Ulrike Glück and Cyndi Cao, 'Intercompany Loans now Possible in China' Lexology (21 Oct 2015) <http://www.lexology.com/library/detail.aspx?g=c67d7c6c-df47-4be8-988f-04d731d3a65b> and Garrigues,
} 
previously under the General Provisions on Lending, ${ }^{164}$ validity of private lending contracts signed between legal entities has been questionable. Article 11 of the Provisions confirms the validity and hence enforceability of a private lending contract entered between legal entities for the purposes of production and business operation. In other words, the private loan contract will still be invalid if the loan is of a fraudulent or criminal nature (either on the lender's or borrower's side or both); or when the loan is obtained from other companies or by fundraising from the employees, and then knowingly re-lent to the borrower for profit purposes. ${ }^{165}$ The latter transaction is clearly the business of a bank or other types of recognised financial institutions and remains forbidden unless conducted by these approved entities. Under the Criminal Law, whoever sets up a commercial bank or any other financial institution without the PBOC's permission is a criminal offence. ${ }^{166}$ But in the context of this article, where illegal fundraising is concerned, it may not be really meaningful for the victims to sue. First, as shown earlier, in many cases the proceeds should probably have been spent by the perpetrators to support their lavish lifestyle. Second, the criminal law provides that the perpetrators' own property used for committing the crime will be confiscated. ${ }^{167}$ These confiscated property, together with fines of the crime will then be handed over to the national treasury. There should not be many other assets left for the victims should a private action succeed.

As discussed, the setting up of a financial institution is strictly regulated by laws such as the Law on Commercial Banks and the Criminal Law. But China is clearly adopting a more liberal view towards accommodating new financial channels. The introduction of a formal regulatory framework for $\mathrm{P} 2 \mathrm{P}$ lending as discussed above is one prominent example. Another example is small loan companies. In 2008, the Guiding Opinions of China Banking Regulatory Commission and the People's Bank of China on the Pilot Operation of Small-sum Loan Companies were issued to trial this new type of financial institution. ${ }^{168}$ Both the CBRC and the PBOC recognised the importance of effective allocation financial resources and guiding the flow of capital to rural areas and underdeveloped areas to foster development. ${ }^{169}$ A small loan company is established with investments from natural persons, enterprises or other social organisations, which does not absorb the public deposits and operates small loan business. ${ }^{170}$ Small loan companies are not classified as banks because they cannot take deposits. Instead they fund themselves through equity, bonds and interbank borrowing. According to the PBOC, as of the end of 2015, there were 8,910 small loan companies in China. ${ }^{171}$ Although China has encouraged the rise of small loan providers, their presence remains small. For example, in the first nine months of 2014, they contributed only a tiny portion (around 1 per cent) of overall lending in China, with loans outstanding totalling RMB 908 billion, compared with RMB 95 trillion in commercial bank loans. ${ }^{172}$

\footnotetext{
'PRC Supreme Court's Latest Provisions on the Trial of Private Lending Cases' (2015)

<http://www.garrigues.com/sites/default/files/documents/china-commentary-4-2015.pdf>.

${ }^{164}$ Order No. 2 (1996) of the People's Bank of China.

${ }^{165}$ Art 14 of the Provisions and Art 52 of the Chinese Contract Law.

${ }^{166}$ Art 174 of the Chinese Criminal Law.

${ }^{167}$ Art 64 of the Chinese Criminal Law.

${ }^{168}$ Order No. 23 (2008) of the China Banking Regulatory Commission.

${ }^{169}$ Ibid. Preamble.

${ }^{170}$ Ibid. Art 1.

${ }^{171}$ People’s Bank of China, 'Report on Small Loan Companies in 2015’ [2015 年小額貸款公司統計數據報告] (2016) <http://www.pbc.gov.cn/goutongjiaoliu/113456/113469/3010843/index.html>.

${ }^{172}$ Gabriel Wildau, 'China's Small Lenders Pull Back as Economy Slows' Financial Times (4 November 2014) <https://www.ft.com/content/6f07a5f4-632d-11e4-9a79-00144feabdc0>.
} 
It can be seen that China has tried their best to deepen their financial markets and improve the regulation, but investors cannot just count on the government to protect them. As the US Supreme Court Justice, Louis Brandeis, once said that 'there is no such thing as an innocent purchaser of stocks'. ${ }^{173}$ When a person invests in any of those organisations or ventures of doubtful validity and of doubtful practices, he or she is not innocent. There is an entry strategy in corporate and financial law, in a sense that investors require some form of systematic disclosure to obtain an adequate supply of information. ${ }^{174}$ In an initial public offering on a stock exchange, a prospectus will serve this purpose. ${ }^{175}$ In accordance with the information within the prospectus, investors can then make an informed decision on whether or not they would like to invest. Senior executives of the issuer will face civil liabilities for false or misleading disclosures. ${ }^{176}$ Even in the case of a private company and placement, this is also true. The shareholders of a company have the right to inspect the financial reports and other documents of the company. ${ }^{177}$ There is nothing to stop a prospective investor from requesting the same, even if he or she is not yet a shareholder. Indeed, China is regarded as a top performer in shareholder protection, performing even better than the UK and the US. ${ }^{178}$ This should give a good degree of confidence to equity investors. On the other hand, creditor protection can be understood in two aspects: contractual and proprietary. ${ }^{179}$ The former prescribes rights against the debtor include covenants and other contractual terms that can restrict the debtor's activities to protect the creditor's interests. However, considering the victims of most illegal fundraising cases are unsophisticated investors, this may mean little to them as they are the deal-taker but not the deal-maker. As a deal-maker, a creditor may negotiate for a proprietary right over any asset of a borrower. Again, unsophisticated investors may not be in a position to request security. Other safeguards are not useful either, such as a minimum capital requirement of business. Zhongjin, as discussed above, had a registered capital of RMB 10 million, which was double the amount required by the law at that time, and way higher than the requirement in, such as the EU, but just around one-fifth of the requirement for the smallest commercial banks in China. ${ }^{180}$ Perhaps common sense is a better safeguard to them, as the old saying goes, 'If it sounds too good to be true, it probably is.'

\section{Conclusion}

The earliest attempt to regulate illegal fundraising in China was seen in the Law on Commercial Banks in 1995. Later the approach was reinforced by the amendments to the Criminal Law in 1997. But the provisions are pretty basic, which contain no more than a sentence to describe the offence. For example, the key line of Article 176 is only, 'Whoever takes deposits from people illegally or in disguised form and disrupts financial order shall be sentenced.' A more severe crime as regulated by Article 192 involving a fraud element is no

\footnotetext{
${ }^{173}$ Quoted in Neil Minow and Robert Monks, Corporate Governance (Wiley, 2011) 141.

${ }^{174}$ Armour et al. (n 122) 33-34.

${ }^{175}$ See for example, Art 14 of the Chinese Securities Law.

${ }^{176}$ See for example, Art 69 of the Chinese Securities Law.

${ }^{177}$ See for example, Art 33 of the Chinese Company Law.

${ }^{178}$ Dionysia Katelouzou and Mathias Siems, 'Disappearing Paradigms in Shareholder Protection: Leximetric Evidence for 30 Countries, 1990-2013' (2015) 15 Journal of Corporate Law Studies 127.

${ }^{179}$ Louise Gullifer and Jennifer Payne, Corporate Finance Law: Principles and Policy (Hart, 2015) 191.

${ }^{180}$ The minimum amount of the registered capital of a joint stock limited company was RMB 5 million. Art 81 of the Company Law 2005. This requirement was completely removed in the Company Law 2013. For the EU, Capital Directive (Directive 2012/30/EU) sets the minimum capital requirement for EU public limited liability companies at EUR 25,000 (around RMB 200,000). See also Art 13 the Law on Commercial Banks regarding the minimum capital requirements for commercial banks.
} 
more complicated, which says, 'Whoever illegally raises funds by fraudulent means [should be] sentenced.' For more than a decade and a half, from 1995 till an attempt from the Supreme People's Court in 2010 to clarify the law, the courts had to make a conviction based on the very brief wordings of the law. The Interpretation is an important and timely move to set out clearly various thresholds which ought to be met to establish a breach. Yet, the state tends to enforce these rules in a pattern that they will use a minor rule (Article 176) for those who have powers and for regular citizens they will not hesitate to go for the most severe rule (Article 192) and sentence. The death sentences made in the high profile cases of Wu Ying and Zeng Chengjie have prompted the state to abolish the death penalty of Article 192 owing to a public outcry. This is consistent to the Chinese move to eliminate capital punishment for non-violent crimes, as a result of its commitment to the International Covenant on Civil and Political Rights.

There has been a call for the decriminalisation of illegal fundraising in the absence of frauds, i.e. Article 176. However, as this article has argued, even in a more developed market like the UK, a criminal sanction can be imposed when, for example, a public offer is made without an approved prospectus. The regime in China is not particularly harsh. Also, public enforcement is indeed a more desirable response to both market failures and incomplete law, especially in the case of China. ${ }^{181}$ Chinese police, formally known as the Ministry of Public Security, does take a proactive stance in enforcing the law on illegal fundraising by for example, establishing an online platform to collect information from a mass of victims to facilitate investigation and conviction. ${ }^{182}$ Decriminalisation of the offence will keep the police out from the regime. A dual criminal-civil regime should work far better than civil remedies alone. Finally, while China has put a lot of efforts in an attempt to perfect its financial markets, for example, by having one of the best shareholder protection regimes in the world now, the genuine protection will always come from common sense. Investors must exercise adequate caution when putting money in lucrative yet dubious investment schemes. The introduction of formal regulation to fill the pre-existing regulatory void in certain new sectors of finance such as P2P lending should also help to reduce the number of dubious players in the market, so as to reach the overarching goal of the Chinese state in maintaining 'the steady growth of capital markets'.

\footnotetext{
${ }^{181}$ See, for example, Katharina Pistor and Chenggang Xu, 'Law Enforcement under Incomplete Law: Theory and Evidence from Financial Market Regulation’ (2002) Columbia Law and Economic Working Paper No. 222 $<$ http://ssrn.com/abstract=396141> 3 .

${ }^{182}$ See $n 77$ above.
} 